\title{
The balanced scorecard as a potential instrument for supporting the planning and improvement of accounting education in South Africa
}

\author{
FNS Vermaak \\ Department of Accounting \\ and Finance \\ University of Pretoria
}

\author{
CJ Cronjé \\ Department of Applied \\ Accountancy \\ University of South Africa
}

\begin{abstract}
This paper illustrates the potential of the balanced scorecard as an instrument for accounting educators to guide, stimulate and sustain efforts in respect of planning and improvement in the accounting education environment. The results of the reported survey among the heads of eleven accounting departments at South African universities support the potential applicability of the balanced scorecard in this regard.
\end{abstract}

Key words

Balanced scorecard

Accounting education

\section{Introduction}

Tertiary institutions are experiencing increasing pressure for greater accountability in respect of the outcomes they produce. Stakeholders of these institutions demand that the institutions should add value in accordance with their involvement. When accountability for actions is required, the ivory towers of the past must make way for transparency. The pressure for greater accountability also applies to sections and departments within these institutions. This study focused on academic departments and on the accounting departments at South African universities in particular.

The success of an accounting department is determined by the extent to which it achieves its predetermined objectives. The achievement of these set objectives is facilitated by strategic planning and continual striving for improvement (Doost 1999; Nelson, Bailey \& Nelson 1998; 
Porter 1985). In this way, progress towards the attainment of success is made in a responsible manner.

To determine whether progress towards the achievement of objectives is actually being made, there should be regular measurement of results. The measures for determining the achievement of objectives should incorporate, as far as possible, all aspects that are measurable. (Ingram, Albright \& Hill 2001:312). An instrument that could possibly serve as an aid in this regard is the balanced scorecard.

In the use of the balanced scorecard, measuring is done from four perspectives, namely the financial; customer; internal business; and innovation and learning perspectives (Kaplan \& Norton 1992; Frigo 2000; Lipe \& Salterio 2000). These perspectives form an integrated set of performance measures that are derived from the company's strategy (Atkinson \& Epstein 2000). The most recent literature consulted, confirms that the key characteristic of the balanced scorecard is that the measures included are linked to the mission and strategy of the organisation (Olve, Roy, \& Wetter 1999; McWatters, Morse, \& Zimmerman 2001; Hilton, Maher, \& Selto 2000; Garrison \& Noreen 2000). Once the strategy has been determined, the question regarding what to measure can be decided by "tying the measures in the balanced scorecard to an organisation's strategies" (Drury 2000:929). These measures should be explicitly designed to inform, motivate and support continuous efforts towards their attainment.

The balanced scorecard retains measures of financial performance, but supplements these measures with measures regarding customers; internal business processes; and learning and growth. It therefore enables organisations to track financial results while monitoring the progress made in respect of building the capabilities needed for their growth.

\section{The balanced scorecard in the accounting education environment}

In the preceding sections, the balanced scorecard was upheld as providing a balanced and holistic view of the present and future performance of for-profit organisations. There are also well-documented successful applications in not-for-profit organisations (Kaplan \& Norton 1996:188; Olve et al 1999:296-308; Flynn 1997:36; Kaplan 2001). Having proved successful in respect of not-for-profit organisations, the balanced scorecard should prove to be an equally valuable management technique in the accounting education environment.

The following research on the balanced scorecard in an accounting environment has been reported: 
- $\quad$ The University of California at San Diego (UCSD) reformulated its administrative function with the use of the balanced scorecard approach (Relyea 1998).

- $\quad$ The balanced scorecard has been used as a management system at a university (Gadinabokao \& Vermaak 1997).

- In April 1997, Chang and Chow (1999) undertook a mail survey of 69 heads of university accounting departments in the United States and Canada. Their purpose was to investigate the extent to which the balanced scorecard has applicability to and benefits for accounting education.

- O'Neil, Bensimon, Diamond and Moore (1999) described how a faculty committee at the Rossier School of Education at the University of Southern California applied the balanced scorecard framework as an assessment and planning mechanism for specific academic programmes with a view to increasing the meaningfulness and effectiveness of the programmes.

Of the above-mentioned projects, only the projects of Chang and Chow (1999) and O'Neil et al (1999) include educational applications of the balanced scorecard. These applications may be of some value for this study.

Chang and Chow (1999:398) highlight two reasons why the balanced scorecard may be suitable for application in an educational environment, namely:

- $\quad$ Like banks and insurance enterprises, educational institutions are service organizations, although possibly only in the nature of their operations.

- In their survey and interviews, the heads of accounting departments generally confirmed that the balanced scorecard could be beneficial to their efforts in respect of accounting education.

O'Neil et al (1999:35) add to the applicability of the balanced scorecard as follows: "... we found the framework particularly adaptable to the unique characteristics of academic organisations".

It appears from the above that the balanced scorecard does have possibilities for application in an educational environment. This study investigates these possibilities in the South African context.

\section{Purpose of the study}

The purpose of this study is to determine whether the balanced scorecard can serve as an instrument for the support of planning and improvement in accounting departments at universities in South Africa. Planning and improvement precipitate the attainment of set objectives. 
The potential of the balanced scorecard as an instrument for measuring the attainment of objectives will therefore be investigated. The purpose is not to replace any of the instruments currently being used. However, the fact that other systems are currently being used successfully "does not imply that better systems do not exist, only that they have not yet been discovered" (Zimmerman 2000:12).

\section{$4 \quad$ Research method}

To investigate the balanced scorecard as a potential instrument for supporting the planning and improvement of accounting education in South Africa, a questionnaire was distributed to the heads of 19 accounting departments at South African universities. Ten questionnaires were also distributed to technikons, but because no response was received from the technikons by the return date, they were not taken into account for the purpose of the study.

The questionnaires were dispatched in August 2001. Some of the questionnaires were sent by e-mail, while others were delivered by hand. The purpose of the study was set out on the cover page. The next page provided a brief exposition of the balanced scorecard. The subsequent sections dealt with background information, for example the province, location, number of courses presented at various levels, full-time/parttime presentation, etc.).

The survey instrument thereafter presented four components of a potential scorecard for an accounting department. The components covered the following four perspectives: Financial perspective ("How do we create value for our stakeholders?"), customer perspective ("What do existing and new customers value about us?"), internal business perspective ("What processes should we excel at to achieve our financial and customer objectives?") and innovation and learning perspective (“Can we continue to improve and create value?").

For each of these components, respondents were requested to indicate on a scale from 1 to 5 (in terms of which $1=$ strongly disagree; $2=$ disagree; 3 = unsure; $4=$ agree; and $5=$ strongly agree) to what extent each of the components was considered applicable for inclusion in the department's potential balanced scorecard. If the respondent had an amendment to propose or a suggestion to make in respect of the components, it was to be indicated in the relevant space.

Furthermore, for each of the components considered applicable for inclusion, respondents were requested to indicate, in accordance with a list of goals and corresponding measures and on a scale from 1 to 5 , which of the options best represented their impression of each measure. The goals and measures were compiled on the basis of the findings of the studies of Chang and Chow (1999) and of O'Neil et al (1999). 
Eleven $(58 \%)$ of the questionnaires that were returned by the due date were found to be usable. In view of this relatively high response rate, it was not considered necessary to follow up the questionnaires that were not returned.

\section{$5 \quad$ Results of the research}

\subsection{General information of respondents}

All 11 respondents gave background information to a greater or lesser extent and, as mentioned above, all were employed at universities. Six $(54,6 \%)$ of the respondents were located in Gauteng, while the others were distributed as follows: $2(18,1 \%)$ in the Western Cape, $1(9,1 \%)$ in the Eastern Cape, $1(9,1 \%)$ in the Free State and $1(9,1 \%)$ in KwaZuluNatal.

All 11 departments have undergraduate accounting programmes, $6(54,6 \%)$ also present honours degree programmes; 4 (36,4\%) present master's degree programmes; and $4(36,4 \%)$ cater for doctoral studies.

The above information indicates that the sample includes a variety of accounting programmes.

\subsection{Possible implementation of the components of the balanced scorecard}

Feedback was requested on the following two questions:

- $\quad$ To what extent are the four components suitable for inclusion in your department's potential balanced scorecard?

- $\quad$ Do you wish to make any changes to or suggestions regarding the components given?

In respect of question 1, a 5-point response scale was used. As mentioned above, the anchors were $1=$ "strongly disagree" and $5=$ "strongly agree".

Table 1 indicates the frequency and percentages in respect of the scale of response given to each component of the balanced scorecard. 
Table 1

\begin{tabular}{|c|c|c|c|c|c|c|c|c|}
\hline & \multicolumn{2}{|c|}{$\begin{array}{c}\text { Financial } \\
\text { perspective }\end{array}$} & \multicolumn{2}{c|}{$\begin{array}{c}\text { Customer } \\
\text { perspective }\end{array}$} & \multicolumn{2}{c|}{$\begin{array}{c}\text { Internal business } \\
\text { perspective }\end{array}$} & \multicolumn{2}{c|}{$\begin{array}{c}\text { Innovation and } \\
\text { learning } \\
\text { perspective }\end{array}$} \\
\hline & Frequency & $\%$ & Frequency & $\%$ & Frequency & $\%$ & Frequency & $\%$ \\
\hline 1 & - & - & - & - & - & - & - & - \\
2 & - & - & - & - & - & - & - & - \\
3 & 2 & 18,2 & - & - & 1 & 9,1 & - & - \\
4 & 3 & 27,3 & 2 & 18,2 & 4 & 36,4 & 5 & 45,5 \\
5 & 6 & 54,5 & 9 & 81,8 & 6 & 54,5 & 6 & 54,5 \\
\hline
\end{tabular}

In respect of each component, more than half $(54,5 \%)$ of the respondents indicated that they "strongly agree".

The two components in respect of which the respondents indicated that they "strongly agree" (scales 4 and 5 ) were the customer perspective and the innovation and learning perspective. This finding is not unexpected, because the customer could be interpreted as being the students and the innovation and learning perspective as being research and continuous improvement. Traditionally, the above are also considered to be reasons for the continued existence of universities.

Respondents displayed a measure of uncertainty regarding the financial perspective $(18,2 \%$ on scale 3$)$ and the internal business perspective $(9,1 \%$ on scale 3$)$. This finding is also not unusual, because these perspectives usually receive less attention than the other measures at academic institutions. However, the majority of respondents agree that these two components should be used. None of the respondents indicated a 1 or 2 on the given scale for any of the components, which implies that the heads of departments were reasonably positive about the potential of the balanced scorecard to benefit their departments.

In respect of question two, three $(27,3 \%)$ of the respondents indicated a total of 4 changes/suggestions. All the changes/suggestions only dealt with a clearer definition of the component, which did not have a fundamental effect on the designation of the component that had been presented.

\subsection{Suggested balanced scorecard measures}

Tables 2 to 5 indicate the goals and the measures of each of the four components. With regard to these measures, only those selected by the respondents with a score of 4 or 5 on the scale in the questionnaire are shown. Only four respondents made a few suggestions regarding further goals and measures and therefore these suggestions are not taken into account in the present context. 


\subsubsection{Financial perspective}

Table 2 indicates the financial performance measures that motivate heads of departments to consider how their departments are perceived by stakeholders.

\section{Table 2}

\begin{tabular}{|l|l|c|l|}
\hline \multicolumn{4}{|l}{$\begin{array}{l}\text { Component one: Financial perspective: How do we create value for our } \\
\text { stakeholders? }\end{array}$} \\
\hline Goals & Measures & $\mathbf{n}$ & $\%$ \\
\hline \multirow{3}{*}{ Prosper } & Annual subsidy to the department & 5 & 45,5 \\
\cline { 2 - 4 } & Amount of donations & 6 & 54,5 \\
\cline { 2 - 4 } & Amount of outside funds & 8 & 72,7 \\
\hline \multirow{2}{*}{ Succeed } & Test / exam results & 8 & 72,7 \\
\cline { 2 - 4 } & Enrolment trend & 10 & 90,9 \\
\hline \multirow{2}{*}{ Survive } & Funding per student & 8 & 72,7 \\
\cline { 2 - 5 } & Level of student enrolment & 10 & 90,9 \\
\hline
\end{tabular}

The greater majority of respondents $(90,9 \%)$ selected "enrolment trend" and "level of student enrolment" as the measures that would be the best indicators of financial success.

In respect of the measurement of the creation of value for stakeholders, a score of $72,7 \%$ was allocated to each of test/exam scores, amount of outside funds and funding per student, which could indicate that heads of accounting departments do not see the outcomes of education and funds as being the most important measures.

The annual subsidy provided to the department and the amounts of donations (i.e. measures regarding which the department's input does not have a direct influence) were selected as being of lesser importance.

Table 2 clearly indicates that, in the creation of value for the stakeholders of a university, measures that relate to quality standards are more important than measures that relate to numbers, and that the emphasis is on success and survival.

\subsubsection{Customer perspective}

Table 3 indicates the measures that encourage heads of departments to consider how their departments are perceived by customers. 


\section{Table 3}

\begin{tabular}{|c|c|c|c|}
\hline \multicolumn{4}{|c|}{$\begin{array}{l}\text { Component two: Customer perspective: What do existing and new } \\
\text { customers value about us? }\end{array}$} \\
\hline Goals & Measures & $\mathbf{n}$ & $\%$ \\
\hline \multirow{3}{*}{$\begin{array}{l}\text { Effective } \\
\text { student } \\
\text { placement }\end{array}$} & $\begin{array}{l}\text { Percentage of students with a job } \\
\text { offer at graduation }\end{array}$ & 6 & 54,5 \\
\hline & $\begin{array}{l}\text { Number of companies recruiting on } \\
\text { campus }\end{array}$ & 6 & 54,5 \\
\hline & $\begin{array}{l}\text { Average starting salaries of } \\
\text { graduates }\end{array}$ & 7 & 63,6 \\
\hline \multirow{3}{*}{$\begin{array}{l}\text { Quality } \\
\text { instruction }\end{array}$} & Alumni evaluation & 7 & 63,6 \\
\hline & Pass rate in professional exam & 10 & 90,9 \\
\hline & Accreditation & 11 & 100 \\
\hline $\begin{array}{l}\text { Highly valued } \\
\text { programme }\end{array}$ & Percentage of applications enrolled & 4 & 36,4 \\
\hline $\begin{array}{l}\text { Quality } \\
\text { academic } \\
\text { advising }\end{array}$ & $\begin{array}{l}\text { Student evaluation of services / } \\
\text { advisory service }\end{array}$ & 9 & 81,8 \\
\hline \multirow{2}{*}{$\begin{array}{l}\text { Flexible } \\
\text { course } \\
\text { scheduling }\end{array}$} & Student satisfaction survey & 9 & 81,8 \\
\hline & $\begin{array}{l}\text { Frequency of presentation of } \\
\text { required courses }\end{array}$ & 9 & 81,8 \\
\hline
\end{tabular}

Accreditation was indicated by all respondents (11) as the measure that indicates what current and new customer's value about universities. Pass rate in professional examination $(90,9 \%)$ was also identified as a popular measure. Three other measures, namely student evaluation of services/advice, student satisfaction survey and the frequency of presentation of required courses also received substantial support. To assess whether the programme was highly valued, the measure "percentage of the applications enrolled" was identified as the weakest measure.

Interestingly, only one respondent identified and recorded staff as a customer class, although it can be argued that the welfare of faculty and other staff is likely to affect the extent to which the other customer classes are served.

Quality instruction is therefore a goal that is highly valued in the selection of the above-mentioned measures. 


\subsubsection{Internal business perspective}

Table 4 contains the results that have a bearing on the encouragement of heads of departments to improve internal processes to ensure customer satisfaction.

\section{Table 4}

\begin{tabular}{|l|l|c|l|}
\hline \multicolumn{4}{|l|}{$\begin{array}{l}\text { Component three: Internal business perspective: What processes } \\
\text { should we excel at to achieve our financial and customer objectives? }\end{array}$} \\
\hline Goals & Measures & $\mathbf{n}$ & $\%$ \\
\hline $\begin{array}{l}\text { Quality } \\
\text { assurance }\end{array}$ & Student competency evaluation & 10 & 90,9 \\
\hline Internship & Student evaluation & 4 & 36,4 \\
\cline { 2 - 4 } & Number of companies involved & 5 & 45,5 \\
\cline { 2 - 4 } & $\begin{array}{l}\text { Number of opportunities for } \\
\text { internships available }\end{array}$ & 6 & 54,5 \\
\hline Cost efficiency & Faculty-to-student ratio & 7 & 63,6 \\
\cline { 2 - 4 } & Educational expenditure per student & 8 & 72,7 \\
\hline $\begin{array}{l}\text { Optimum class } \\
\text { size }\end{array}$ & $\begin{array}{l}\text { Average class size compared to } \\
\text { other institutions }\end{array}$ & 4 & 36,4 \\
\cline { 2 - 4 } & Average class size for majors & 8 & 72,7 \\
\hline $\begin{array}{l}\text { Unique or } \\
\text { specialised } \\
\text { curriculum }\end{array}$ & $\begin{array}{l}\text { Number of other departments } \\
\text { offering the same programme }\end{array}$ & 6 & 54,5 \\
\hline
\end{tabular}

Student competency evaluation $(90,9 \%)$ was indicated as the best measure by means of which to rate internal systems.

Other useful measures are educational expenditure per student and average class size for majors.

Three measures, namely student evaluation $(36,4 \%)$, average class size in comparison with other institutions $(36,4 \%)$ and number of companies involved in internships $(45,5 \%)$ were identified as having a low value.

\subsubsection{Innovation and learning perspective}

Table 5 addresses the results regarding the learning and growth perspective in respect of which heads of departments were requested to consider what is required to meet the goals of the financial, customer and internal business perspectives. 


\section{Table 5}

\begin{tabular}{|c|c|c|c|}
\hline \multicolumn{4}{|c|}{$\begin{array}{l}\text { Component Four: Innovation and learning perspective: Can we } \\
\text { continue to improve and create value? }\end{array}$} \\
\hline Goals & Measures & $\mathbf{n}$ & $\%$ \\
\hline \multirow{4}{*}{$\begin{array}{l}\text { Professional } \\
\text { growth in } \\
\text { department }\end{array}$} & $\begin{array}{l}\text { Travel budget for attendance of } \\
\text { conferences }\end{array}$ & 6 & 54,5 \\
\hline & $\begin{array}{l}\text { Number of presentations by } \\
\text { departmental staff at conferences }\end{array}$ & 8 & 72,7 \\
\hline & $\begin{array}{l}\text { Number of seminars attended by } \\
\text { departmental staff }\end{array}$ & 8 & 72,7 \\
\hline & Number of departmental publications & 9 & 81,8 \\
\hline $\begin{array}{l}\text { Incorporating } \\
\text { technology } \\
\text { into teaching }\end{array}$ & $\begin{array}{l}\text { Number of courses that incorporate } \\
\text { new technology }\end{array}$ & 9 & 81,8 \\
\hline \multirow[t]{2}{*}{$\begin{array}{l}\text { Innovation in } \\
\text { teaching }\end{array}$} & $\begin{array}{l}\text { Number of teaching workshops } \\
\text { attended by departmental staff }\end{array}$ & 5 & 45,5 \\
\hline & Number of teaching innovation projects & 9 & 81,8 \\
\hline \multirow[t]{2}{*}{$\begin{array}{l}\text { Curriculum } \\
\text { innovation }\end{array}$} & $\begin{array}{l}\text { Number of curriculum revisions in past } \\
\text { five years }\end{array}$ & 7 & 63,6 \\
\hline & $\begin{array}{l}\text { Number of new courses offered in the } \\
\text { past five years }\end{array}$ & 7 & 63,6 \\
\hline \multirow{2}{*}{$\begin{array}{l}\text { Partnering with } \\
\text { accounting/bu } \\
\text { siness firms }\end{array}$} & Number of joint activities & 6 & 54,5 \\
\hline & $\begin{array}{l}\text { Number of firms involved in joint } \\
\text { activities }\end{array}$ & 7 & 63,6 \\
\hline
\end{tabular}

For the monitoring of innovation and learning, five measures were considered to be especially useful: the number of presentations by departmental staff at conferences; number of seminars attended by departmental staff; number of departmental publications; number of courses that incorporate new technology; and number of teaching innovation projects.

It is interesting to note that the measure "number of teaching workshops attended by departmental staff" received a low ranking. The above research results indicate that heads of departments consider some measures to be more important than others. However, tables 2 to 5 reveal that a wide variety of measures can be used to construct the balanced scorecard for an accounting department.

\section{Conclusions}

Accounting educators are increasingly seeking effective ways to fulfil their stakeholders' demand for greater accountability. Performance measurement is essential in this process. It indicates direction and 
provides feedback on the effectiveness of planning, execution of plans, attainment of goals and efforts to improve. The balanced scorecard, which has been adopted by many for-profit organisations, therefore merits consideration in this regard.

The heads of accounting department that were surveyed, indicated that they were reasonably positive about the potential benefits of the balanced scorecard for the accounting education environment. In most cases, the heads of departments agreed with the measures that were provided. It is an indication that it would be meaningful to include these goals and measures in the construction of an effective balanced scorecard for an accounting department.

The results of the research indicate that the balanced scorecard does contain possibilities that are supplementary to existing tools and that it is a potential instrument for supporting the planning and improvement of the accounting education environment.

This research could be extended to other countries in a comparative study to identify the meaningful goals and measures that could be included in the balanced scorecards of universities worldwide.

\section{Bibliography}

Atkinson, A. and Epstein, M. 2000. Measure for measure, CMA Management, Vol. 74, No. 7, pp.22-28.

Chang, O.H. and Chow, C.W. 1999. The Balanced Scorecard: A potential tool for supporting change and continuous improvement in accounting education, Issues in Accounting Education, Vol. 14, No. 3, pp.395-412.

Doost, R.K. 1999. The missing links in Accounting Education, Managerial Auditing Journal, Vol. 14. No. 3, pp.93-114.

Drury, C. 2000. Management and Cost Accounting, Business Press, London.

Frigo, M.L. 2000. 2000 CMG Survey on Performance Measurement: Balanced Scorecard Linked to Better Performance Measures, Cost Management Update, Vol. 108, pp.1-2.

Flynn, G. 1997. How the Bank of Montreal keeps score on success, Workforce, Vol. 76, No. 12, pp.36.

Gadinabokao, W.L. and Vermaak, F.N.S. 1997. The Balanced Scorecard: Application as Management System at a University, Meditari, pp.243-260. 
Garrison, R.H. and Noreen, E.W. 2000. Managerial Accounting, Irwin McGraw-Hill, Boston.

Hilton, R.W., Maher, M.W. and Selto, F.H. 2000. Cost Management: Strategies for Business Decisions, Irwin McGraw-Hill, Boston.

Ingram, R.W., Albright, T.L. and Hill, J.W. 2001. Managerial Accounting: Information for Decisions, South Western College Publishing, Cincinnati.

Kaplan, R.S. 2001. Strategic Performance Measurement and Management in Nonprofit Organizations, Nonprofit Management and Leadership, Vol. 11, No. 3, pp.353-370.

Kaplan, R.S. and Norton, D.P. 1996. The Balanced Scorecard: Translating Strategy into Action, Harvard Business School Press, Boston.

Kaplan, R.S. and Norton, D.P. 1992. The Balanced Scorecard Measures That Drive Performance, Harvard Business Review, Vol. 70, No. 1, pp.71-79.

Lipe, M.G. and Salterio, S.E. 2000. The Balanced Scorecard: Judgmental Effects of Common and Unique Performance Measures, The Accounting Review, Vol. 75, No. 3, pp.283-298.

McWatters, C.S., Morse, D.C. and Zimmerman, J.L. 2001. Management Accounting: Analysis and Interpretation, McGraw-Hill, Boston.

Nelson, I.T., Bailey, J.A. and Nelson, A.T. 1998. Changing accounting education with purpose: Market-based strategic planning for departments of accounting, Issues in Accounting Education, Vol. 13, No. 2, pp.301-326.

O'Neil, H.F., Bensimon, E.M., Diamond, M.A. and Moore, M.R. 1999. Designing and Implementing an Academic Scorecard, Change, Vol. 31, No. 6, pp.33-40.

Olve, N., Roy, J.R. and Wetter, M. 1999. Performance Drivers: A Practical Guide to Using the Balanced Scorecard, John Wiley \& Sons, Chichester.

Porter, M.E. 1985. Competitive Advantage: Creating and Sustaining Superior Performance, The Free Press, New York.

Relyea, S.W. 1998. From Gutter Balls to Strikes, Business Officer, June 1998.

http://www.nacubo.org/website/members/bomag/9806/scorecard.html

Zimmerman, J.L. 2000. Accounting for Decision Making and Control, McGraw-Hill, Boston. 